\title{
A Novel Framework for Urban Flood Damage Assessment
}

\section{Fatemeh Yavari}

Tarbiat Modares University

Seyyed Ali Akbar Salehi Neyshabouri

Tarbiat Modares University

Jafar Yazdi

Shahid Beheshti University

amir molajou ( $\square$ amolajou@yahoo.com )

Iran University of Science and Technology

\section{Research Article}

Keywords: Urban flood damage, rainfall non-stationarity, urban development, HEC-RAS2D, HEC-FIA

Posted Date: December 1st, 2021

DOI: https://doi.org/10.21203/rs.3.rs-991898/v1

License: (c) (i) This work is licensed under a Creative Commons Attribution 4.0 International License. Read Full License

Version of Record: A version of this preprint was published at Water Resources Management on April 6th, 2022. See the published version at https://doi.org/10.1007/s11269-022-03122-3. 


\section{Abstract}

The study of non-stationary effects of hydrological time series and land-use changes in urban areas is essential to predict future floods and their probable damage. In the current study, a novel method was proposed for analyzing their simultaneous impact. For this purpose, rainfall frequency and land-use changes analyses were conducted for two different long-term periods, and the results were compared. Then, hydrologic modeling of the catchment was carried out using the HEC-HMS model, and obtained hydrographs were fed to the HEC-RAS2D model for estimating flood inundation areas. Using the economic information of assets and their damage functions, flood damages related to these two periods were evaluated through the HEC-FIA model. The results indicated that in the low return periods (e.g., 2-year flood), the damage in the second period was increased with respect to the first one but increased for the return periods of 5 to 100 years. Furthermore, surface runoff showed a $4.65 \%$ increase due to land-use change and a $12 \%$ increase due to rainfall non-stationarity. Moreover, flood damage showed a $136 \%$ increase on average, and among the two studied factors, the non-stationarity of rainfalls is considerably more effective on flood intensification.

\section{Introduction}

Flood is one of the natural disasters that causes a lot of damage to human societies every year. Meanwhile, cities have the highest risk and probability of flood damage (Hallegatte et al., 2013; Chen et al., 2016; Jiang et al., 2018). Urbanization is a global trend and is not limited to some countries. At the beginning of the 21 st century, the world's urban population has reached $50 \%$ of the world's population and is projected to exceed $61 \%$ by 2025 . That is why studies related to urban floods are becoming more and more important, and many researchers from all over the world are focusing on it (Mark et al., 2004; Maksimović et al., 2009; Seyoum et al., 2012; Henonin et al., 2013; Moftakhari et al., 2017; Jamali et al., 2018).

Structural flood control measures have been one of the dominant methods of flood management for many years. However, in recent years, this traditional method has been seriously questioned due to high uncertainty in determining the design flood due to various reasons such as climate change and changing rainfall patterns (Song and Chung, 2016). In contrast, new methods have been introduced and developed that place more emphasis on non-structural control measures. The most important achievement in this field has been the change of policies from crisis management to flood risk management (Söderholm et al., 2018).

In recent decades, many studies have been conducted on flood risk reduction programs, especially in urban areas (Ten Veldhuis, 2011; Tsakiris, 2014; Hammond et al., 2018; Park and Lee, 2019; Nofal et al., 2020, Mubeen et al., 2021). It is obvious that the proper and effective planning and implementation of various programs to reduce the destructive effects of floods and preparedness against them requires evaluating the effects of this event and accurately estimating the amount of damage to different sections of society (Dutta et al., 2003; Pingel and Ford, 2004; Merz et al., 2010; Hammond et al., 2015; Wobus et al., 2013; Wedawatta et al., 2014; Chen et al., 2016; Martins et al., 2018; Jiménez-Jiménez et al., 2020). Hence, a comprehensive set of flood studies focuses on flood damage assessment and examines its various aspects (Freni et al., 2010; Notaro et al., 2014; Tate et al., 2014; Arighi and Campo, 2019).

Previous studies have shown that various parameters should be considered in urban flood modeling. One of the most important of these parameters, which has been emphasized in previous studies, is the non-stationarity in rainfall (Vasiliades et al., 2014; Salas et al., 2014; Yang et al., 2020). The uncertainties in flood damage 
assessments are decreased via the interrelated factors, such as the rates of climate change and urbanization in urban flood simulations. In other words, the alternations in flood frequency could be the result of the combined effects of climate changes and human activities. Consequently, considering the effects of non-stationarity in rainfalls leading to extreme urban floods, hydrological modelling would help the future hydraulic urban flood map simulations and urban flood damage assessments to have higher accuracy.

Another important parameter in urban flood damage modeling is an urban development that should be considered in urban flood modeling and flood losses (Vogel et al., 2011, Kaspersen et al., 2017; Zhou et al., 2019; Hodgkins et al., 2019). To be more specific, since land-use changes have altered the pattern of green spaces in urban areas as the result of the numerous buildings and streets made leading to the diminution of permeable surfaces, the imbalance in the natural water cycle has increased. Therefore, the time that runoff reaches the peak has decreased, in contrast to flood volume and flood peak discharge (James, 1965; Lorup et al., 1998, Campana and Tucci, 2001; Ranzi et al., 2002; Liu et al., 2005; Nirupama and Simonovic, 2007; Saghafian et al., 2008; Suriya and Mudgal, 2012; Miller et al., 2014; Cutter et al., 2018).

According to the studies that the authors have done, there has been no focus on how the combination of the factors of urban development and non-stationarity in rainfalls affect urban flood damages modelling. As a novel strategy, in the current study, it was tried to fill this gap, and the authors assessed the rate of each of these factors' effects and also both of them simultaneously on hydrological and hydraulic urban flood simulations, and economical damages of the future forecasted floods having various return periods. Besides, rainfall nonstationary conditions have been previously studied mostly using statistical analysis in the literature. It should be mentioned that the simultaneous use of statistical methods and hydrological/hydraulic modeling has been considered in the present study.

\section{Materials And Methods 2.1 Proposed method}

The main steps of the proposed method in the present study are shown in Figure 1.

As it can be seen in Figure 1, as a first step, the mentioned required data, such as rainfall and runoff time series, sub-basins information, and land-use maps, were collected. In the second part, the rainfall-runoff modeling was done using the HEC-HMS model, the maximum discharges were calculated, and also calibration and verification were done. In the following, the outcomes of hydrographs were applied in HEC-RAS2D, and flood maps for the target return periods were obtained. After that, as a fourth step, the flood maps obtained before were applied in HEC-FIA to serve the flood damage assessments. It should be noted that, in all of the process of simulations, the results of the considered periods were compared to appraise the effects of rainfall non-stationary conditions and urban development. Furthermore, the models were selected since they could be linked with each other, helping the accuracy and the speed of modeling with high efficiency.

\subsection{Study Area}

The West-Main Channel catchment is located in the west and northwest of Tehran and is one of the main components of the drainage system in Tehran city (Figure 2). It drains most of the floods in the northern, 
northwest, and west of Tehran. The catchment area is $433 \mathrm{~km}^{2}$, from which $283 \mathrm{~km}^{2}$ is non-urban, and $150 \mathrm{~km}{ }^{2}$ areas are urbanized. The details of the sub-catchments are listed in Table 1.

The maximum and minimum altimetry in the catchment is $1420 \mathrm{~m}$ and $1125 \mathrm{~m}$, respectively. The average annual rainfall in Tehran is about $320 \mathrm{~mm}$. Streams in the north, i.e., in non-urban sub-catchments, are mainly mountainous rivers with flash flood regimes, and inside the city, they are converted to man-made concrete channels. In Figure 2, the boundary of urban and mountainous areas is shown by a red line. The boundary of the studied catchment was also shown in yellow. The Jahan-Abad hydrometric station is located at the end of the West Main Channel catchment.

Table 1

Sub-catchments information in the study area

\begin{tabular}{|llllllll|}
\hline $\begin{array}{l}\text { Sub- } \\
\text { Catch. }\end{array}$ & Type of area & $\begin{array}{l}\text { Area } \\
\left(\mathbf{k m}^{2}\right)\end{array}$ & $\begin{array}{l}\text { Tc } \\
(\mathbf{m i n})\end{array}$ & $\begin{array}{l}\text { Sub- } \\
\text { Catch. }\end{array}$ & Type of area & Area $\left(\mathbf{k m}^{2}\right)$ & Tc (min) \\
\hline W01 & Mountainous & 25.5 & 50 & W13 & Mountainous & 2.5 & 30 \\
\hline W02 & Mountainous & 3.3 & 27 & W14 & Mountainous & 4.3 & 36 \\
\hline W03 & Urban & 3.3 & 15 & W15 & Urban & 4.8 & 18 \\
\hline W04 & Mountainous & 1.7 & 34 & W16 & Urban & 3.1 & 22 \\
\hline W05 & Urban & 1.3 & 15 & W17 & Urban & 9.5 & 37 \\
\hline W06 & Urban & 2.4 & 18 & W18 & Urban & 8.5 & 24 \\
\hline W07 & Urban & 1.4 & 16 & W19 & Urban & 2.3 & 18 \\
\hline W08 & Urban & 4.9 & 24 & W20 & Urban & 2 & 22 \\
\hline W09 & Urban & 8.4 & 25 & W21 & Mountainous & 14.6 & 38 \\
\hline W10 & Urban & 5.4 & 21 & W22 & Urban & 4.5 & 16 \\
\hline W11 & Mountainous & 21.7 & 55 & W23 & Urban & 4.7 & 21 \\
\hline W12 & Urban & 2.3 & 13 & & & & \\
\hline
\end{tabular}

\subsection{Data collection}

\subsubsection{Required data for the hydrological modeling}

For hydrological modeling, rainfall data with one-minute time steps from 1979 to 2019 at Niavaran rainfall station ( $X=543001, Y=3963312$, WGS 1984 UTM Zone 39) were first collected. It is noticeable that among the existing meteorological stations in Tehran, Niavaran Station had the longest period of recorded continuous rainfalls. It should be noted that for studying the non-stationary effects, two statistical periods of 1979-2009 and 1979-2019 were considered.

For reliable estimation of rainfall quantiles, the length of the maximum annual time series should be long enough; thus, we defined only two periods over the available time period of data. Also, the land use map in 2009 was used for the first period and 2019 for the second period (i.e., the last year in each period was selected). Land use maps for the two mentioned periods accompanied with the service area of each urban channel and the map of soil 
hydrological groups of the region were prepared. The hydrologic model of the urban catchment was prepared based on this information.

\subsubsection{Required data for hydraulic modeling and preparation of the flood inundation map}

Required data for the hydraulic analysis include geometric data of the channels, including the slope and shape of the channel's section in order to define reaches and channels; topographic data of streets, walkways, and urban features; Manning roughness coefficients and data associated with the existing inline structures along the main channel in the study area (USACE, 2016). A digital elevation model (DEM) with a resolution of $1 \mathrm{~m}^{2}$ was prepared using Pleiades1Tri-Stereo. The hydrographs of sub-catchments for the considered floods were calculated using the calibrated HEC-HMS hydrologic model and entered into the hydraulic model along the main channel (see Figure 2) at specific boundaries. In the present study, one input boundary at the beginning, four input boundaries along the channel, and one output boundary at the end of the channel were defined. The HEC-RAS2D hydraulic model was used in this study.

\subsubsection{Required data to evaluate the flood damage}

In order to evaluate the economic damage of floods, the HEC-FIA model was used (US Army Corps of Engineers, 2012). The digital elevation model (DEM), depth-damage curves of different land uses, the map of flood inundation depth (which is the output of the HEC-RAS2D hydraulic model), building occupancy (residential, industrial, administrative, and commercial), was introduced into the HEC-FIA model. For the purpose of flood damage analysis, depth-damage curves of the buildings considering their occupancy as well as the depth-damage curves of their contents were used in this model (HEC-FIA User's Manual, 2012). The residential, commercial, administrative, and industrial occupancies were considered.

\subsection{Research methods}

\subsubsection{Hydrologic modeling}

The HEC-HMS model was selected for hydrologic modeling, in which the Natural Resources Conservation Service (NRCS) method was used to estimate rainfall loss and excess rainfall. In this method, the physical properties of the land use are considered based on a number called curve number $(\mathrm{CN})$ considering the soil characteristics as well as its moisture during rainfall, which its value can be derived from standard tables. The overall CN of a subcatchment is obtained by averaging the curve numbers of different land uses and weighting based on the area of each land use (Chow et al., 1962). In the next step, the NRCS unit hydrograph method was used to convert excess rainfall to surface runoff, and the reason was that the $\mathrm{CN}$ method is one of the most widely used within hydrological models because of its simplicity. Muskingum method was used to route surface hydrographs of subcatchments in the channel/rivers of the catchment (Chow et al., 1962).

In order to do rainfall frequency analysis and extraction of rainfalls with different return periods, the following procedure is used for two different statistical periods: 1979-2009 and 1979-2019. Using the rainfall data of Niavaran station with one-minute time steps, the maximum annual rainfalls with a duration equal to the time of concentration of the catchment was first derived, according to recorded rainfalls between 1979 and 2019. Then, the best probabilistic distribution function was fitted to the maximum annual time series. The log-normal distribution was recognized as the appropriate function. Using the fitted distribution, floods with return periods of 
$2,5,10,20,25,50$, and 100 years were estimated separately for each statistical period. Finally, using the short rainfalls temporal pattern proposed by the World Meteorological Organization (World Meteorological Organization, 1969) and selection of a 5-minute time step, the rainfall depths with different return periods were distributed during the duration time (equal to the time of concentration of the catchment), and the obtained rainfall hyetographs were introduced to the HEC-HMS model.

\subsubsection{Flood zoning}

HEC-RAS2D numerical model (USACE, 2016) was used to provide flood zoning maps. The topographic information, including the channel cross-sections and the urban environment data as the digital elevation model (DEM), was introduced to the model, and the study area meshed considering the appropriate mesh dimensions (which was determined after sensitivity analysis). Then, the boundary conditions of the Main Flood Channel, including the upstream, downstream, and intermediate boundary conditions along the channel, were defined. To define the Manning coefficient map, the concrete channel and flood plain were defined separately. Eleven inline structures along the channel were also modeled. Finally, considering the unsteady flow simulation, the parameters of numerical solving were adjusted.

\subsubsection{Estimation of the economic damage}

In order to estimate the economic damage, the HEC-FIA model was employed. Data including DEM, the flood zoning maps of different floods obtained by the HEC-RAS2D model, the depth-damage curves for the main land use in the area including the residential, administrative, commercial, and industrial buildings, as well as the economic information related to the structures type and their contents in the mentioned occupancies were collected and used in modeling. The land uses located in flood inundation zone are predominantly included commercial, administrative and residential buildings. The economic values of different land uses were obtained by extensive field studies. Unfortunately, there is no depth damage available for the urban assets in Tehran at present. In the guideline of "Flood Damage Consideration" in Iran, the flood depth-damage curves of different land use in the USA (proposed by USACE, 2003) were presented and suggested for areas without information (Ministry of Energy, 2016), and here these relative curves were used. Figure 3 shows the depth-damage curves used for structures and their contents.

\section{Calibration And Verification Of The Hydrological Model}

The simulated hydrographs of the HEC-HMS model were compared with the observed hydrographs in the calibration and verification stages. In order to calibrate, model parameters, including the $\mathrm{K}$ parameter in the Muskingum method, the lag time, and the initial losses in the NRCS method, were considered as the calibration parameters. The present study used statistical criteria, including the correlation coefficient $(R)$ and the root mean squared error (RMSE), to assess modeling results.

The correlation coefficient has a range of changes between -1 to +1 . A value of zero for this coefficient indicates that there is no relationship between observational and computational data. The closer it is to -1 or +1 , the greater the correlation between the mentioned data. Another criterion, RMSE, with an amplitude of variation $(0,+\infty)$ is acceptable (Wang et al., 2009). 


$$
\begin{aligned}
& R=\frac{\frac{1}{n} \sum_{i=1}^{n}\left(Q_{0}(i)-\bar{Q}_{0}\right)\left(Q_{f}(i)-\bar{Q}_{f}\right)}{\sqrt{\frac{1}{n} \sum_{i=1}^{n}\left(Q_{0}(i)-\bar{Q}_{0}\right)^{2} * \sqrt{\frac{1}{n} \sum_{i=1}^{n}\left(Q_{f}(i)-\bar{Q}_{f}\right)^{2}}}} \\
& R M S E=\sqrt{\frac{1}{n} \sum_{i=1}^{n}\left(Q_{f}(i)-Q_{0}(i)\right)^{2}}
\end{aligned}
$$

Where $\mathrm{n}$ is the number of data, ${ }^{Q_{0}(i)}$ is computed value, ${ }^{Q_{f}(i)}$ is observed data, $\bar{Q}_{0}$ is the average of computed data, and $\overline{Q_{r}}$ is the average of observed data.

To calibrate and validate the model, rainfall data of five synoptic stations in Tehran for the considered events is served to the hydrological model, and the related hydrographs were extracted. Then, these hydrographs were compared with the observed ones at Jahan-Abad hydrometric station. According to the level of errors, the model parameters were changed to achieve the best agreement between the model hydrographs with observed ones. For the calibration of parameters, the event $8 / 29 / 2011$ and for the verification, the event on $3 / 31 / 2009$ was used (Table2).

Table 2

The statistical indices of the calibration and validation error

\begin{tabular}{|lll|}
\hline Criteria & $\boldsymbol{R}^{2}$ & RMSE \\
& $\left(\mathrm{m}^{3} / \mathrm{s}\right)$ & \\
\hline Calibration & 94 & 5.35 \\
\hline Validation & 89 & 4.66 \\
\hline
\end{tabular}

Based on Table 2, simulations in the calibration and verification stages are in the acceptable level. The comparison of the calculated and observed hydrographs at the calibration and verification stages is shown in Figures 4 and 5, respectively.

\section{Results And Discussion}

\subsection{Estimation of rainfalls with different return periods, considering non-stationary conditions}

Using the log-normal probability distribution, changes in extreme rainfalls for the 30-year period of 1979-2009 and the 40-year period of 1979-2019 were studied. The probabilistic characteristics of rainfalls in two periods were 
calculated and presented in Table 3. Then, the maximum rainfalls with different return periods of 2, 5, 10, 20, 25, 50 , and 100 years were obtained through using the function of the log-normal distribution (see Table 4).

Table 3

Mean and standard deviation of the rainfall statistical distribution using log-normal function

\begin{tabular}{|llll|}
\hline $\begin{array}{l}\text { Log-Normal Statistical } \\
\text { Distribution Parameters }\end{array}$ & $\begin{array}{l}\text { First } \\
\text { statistical } \\
\text { period } \\
\text { (1979-2009) }\end{array}$ & $\begin{array}{l}\text { Second } \\
\text { statistical } \\
\text { period }\end{array}$ & $\begin{array}{l}\text { Percent change in statistical } \\
\text { distribution parameters (\%) }\end{array}$ \\
\hline Mean $(\mathrm{mm})$ & 2.36 & 2.35 & \\
\hline standard deviation $(\mathrm{mm})$ & 0.35 & 0.4 & -0.43 \\
\hline
\end{tabular}

Table 4

Rainfall depths with different return periods ( $\mathrm{mm}$ )

\begin{tabular}{|llll|}
\hline $\begin{array}{l}\text { Return } \\
\text { period } \\
\text { (year) }\end{array}$ & $\begin{array}{l}\text { Rainfall depth with respect to } \\
\text { the first period }(\mathrm{mm})\end{array}$ & $\begin{array}{l}\text { Rainfall depth with respect to the } \\
\text { second period }(\mathrm{mm})\end{array}$ & $\begin{array}{l}\text { Percentage of rainfall } \\
\text { changes }(\%)\end{array}$ \\
\hline 2 & 10.59 & 10.49 & -0.94 \\
\hline 5 & 14.22 & 14.68 & +3.23 \\
\hline 10 & 16.59 & 17.51 & +5.55 \\
\hline 20 & 18.83 & 20.25 & +7.54 \\
\hline 25 & 19.55 & 21.12 & +8.03 \\
\hline 50 & 21.73 & 24.84 & +9.71 \\
\hline 100 & 23.91 & 26.59 & +11.21 \\
\hline
\end{tabular}

According to Table 4, there was a decrease of $0.94 \%$ in the 2 -year rainfall in the second period in comparison with the first one. It is attributable to the change in the maximum annual rainfalls, which partly concentrated around the mean value of the time series. It has altered the frequency of maximum annual rainfalls and related probability distribution functions. For higher return periods, however, due to the extending the range of annual extreme data, the obtained probability distribution had higher skewness, and therefore, the quantiles of rainfalls and related surface runoff have increased. That is to say, by increasing the return period, the changes in the rainfall depth also increased.

\subsection{Calculation of $\mathrm{CN}$ for sub-catchments and investigating the urban development conditions}

$\mathrm{CN}$ for each of the sub-catchments can be calculated considering the land use types (Figure7). The spatial distribution of the urban development and land-use changes in terms of CN is shown in Figure 8a (in 2009) and Figure $8 \mathrm{~b}$ (in 2019), comparing the land-use changes between two time periods for different sub-catchments.

According to Figures 7 and $8, \mathrm{CN}$ has increased in most of the sub-catchments, due to the expansion of the impervious surface areas, as a result of urban development. It is obvious that the runoff has been increased. As 
can be seen in Figures 7 and 8, sub-catchments no. w16, w17, and w20, with an average increase of about $8 \%$ in $\mathrm{CN}$, showed the locations affected noticeably due to urban development.

\subsection{Estimation of runoff regarding both effects of urban development and non-stationary rainfall}

In order to investigate the effects of rainfall non-stationary conditions and urban development on the runoff volume, the maximum discharge at the outlet of the catchment was first estimated using the hydrological model for the first period via considering the statistical data of the 30-year period of 1979-2009 and land use conditions in 2009.

In the second step, the rainfall-runoff modeling was performed by regarding the rainfall non-stationary conditions and using the data of the 40-year statistical period of 1979-2019 and land use conditions in 2009. In the third part, the urban development conditions and $\mathrm{CN}$ changes were investigated, and the modeling was repeated using the 30-year statistical data of 1979-2009 and land use conditions in 2019. Finally, as the second period (considering the statistical data of the 40-year period of 1979-2019 and the land use conditions in 2019), the rainfall nonstationary conditions and urban development were applied simultaneously in the model. The simulation results and their effects for the floods with different return periods are presented in Table 5.

Table 5

The magnitude of floods with different return periods, considering the rainfall non-stationary conditions, and urban development

\begin{tabular}{|c|c|c|c|c|c|c|c|}
\hline $\begin{array}{l}\text { Return } \\
\text { period } \\
\text { (Years) }\end{array}$ & $\begin{array}{l}\text { Flood } \\
\text { discharge } \\
\text { for the } \\
\text { first } \\
\text { period } \\
\left(\mathrm{m}^{3} / \mathrm{s}\right)\end{array}$ & $\begin{array}{l}\text { Flood } \\
\text { discharge } \\
\text { considering } \\
\text { the non- } \\
\text { stationarity } \\
\text { of rainfall } \\
\left(\mathrm{m}^{3} / \mathrm{s}\right)\end{array}$ & $\begin{array}{l}\text { Change } \\
\text { percentage } \\
\text { of flood } \\
\text { discharge } \\
\text { related to } \\
\text { rainfall (\%) }\end{array}$ & $\begin{array}{l}\text { Flood } \\
\text { discharge, } \\
\text { considering } \\
\text { the urban } \\
\text { development } \\
\left(\mathrm{m}^{3} / \mathrm{s}\right)\end{array}$ & $\begin{array}{l}\text { Change } \\
\text { percentage } \\
\text { of flood } \\
\text { discharge } \\
\text { related to } \\
\text { urban } \\
\text { development } \\
\text { (\%) }\end{array}$ & $\begin{array}{l}\text { Flood } \\
\text { discharge } \\
\text { for the } \\
\text { second } \\
\text { period } \\
\left(\mathrm{m}^{3} / \mathrm{s}\right)\end{array}$ & $\begin{array}{l}\text { Change } \\
\text { percentage } \\
\text { of flood } \\
\text { discharge } \\
(\%)\end{array}$ \\
\hline 2 & 46.7 & 46.2 & -1.1 & 47.3 & 1.3 & 46.9 & 0.4 \\
\hline 5 & 68 & 72.1 & 6 & 69.6 & 2.4 & 74.2 & 9.1 \\
\hline 10 & 83.4 & 86.2 & 3.4 & 92.4 & 10.8 & 95.8 & 14.9 \\
\hline 20 & 99.2 & 114.2 & 15.1 & 103 & 3.8 & 119.1 & 20.1 \\
\hline 25 & 104.5 & 121.5 & 16.3 & 108.7 & 4 & 127 & 21.5 \\
\hline 50 & 121.6 & 146.2 & 20.2 & 127 & 4.4 & 153.2 & 26 \\
\hline 100 & 139.7 & 173 & 23.8 & 146.3 & 4.7 & 182 & 30.3 \\
\hline
\end{tabular}

As it can be seen in Table 5, for floods with return periods of 5, 10, 20, 25, 50, and 100 years, considering just urban development, the maximum runoff discharge is increased by $2.4,10.8,3.8,4,4.4$ and $4.7 \%$, respectively. For the same return periods, when only the non-stationary condition is considered, the maximum runoff discharge will be increased by $6,3.4,15.1,16.3,20.2$, and $23.8 \%$, respectively.

Analysis of the results shows that for a flood with a 2-year return period, consideration of rainfall non-stationarity decreases the maximum flood discharge and reduces the effect of urban development. For the rest of the return 
periods, the combination of these two factors enhances flood magnitudes. Moreover, the results indicate that certain change in rainfall depth leads to more amount of change in the runoff, for example, around $24 \%$ change in rainfall leads to nearly $30.5 \%$ change in the runoff for a 100 -year flood. According to the outcomes shown in Table 5 , for most of the return periods, non-stationarity of rainfalls is more effective than the urban development in the increase of flood maximum discharge, and both effects together implying they slightly strengthen each other on flood generation. It should be noted that the cumulative effects are expected to be more severe for fully mountainous catchments with steep rivers and the potential of creating floods, causing the importance of flood forecasting and flood risk management in these areas. In the following, the outflow hydrographs of the catchment in two considered statistical periods are shown in Figure 9.

As it can be seen in Figure 9, comparing the hydrographs indicates that by extending the return period, the difference between the maximum discharges of two periods has increased. Particularly, 100-year flood obtained by 30 -year data is less than 50 -year flood obtained by 40 -year data period or 25 -year flood in the latter is larger than 50-year in the former. This point accentuates the necessity of considering non-stationarity in rainfall time series in flood studies, such as the design of levees and the acceptable levels of related risks. For the study area, the West Main Channel (Figure 1) was designed based on a 25-year flood (i.e., with a $4 \%$ risk of failure) around 50 years ago.

\subsection{Flood zoning results using HEC-RAS-2D hydraulic model}

In order to obtain a flood zoning map, hydrographs derived from the HEC-HMS model for each rainfall scenario were imported to the hydraulic model as boundary conditions, and the hydraulic model was performed. Flood maps are generated based on the hydrological analysis of two statistical periods, which are demonstrated in previous sections. The metrics of flood zones obtained by hydraulic simulation results are presented in Table 6.

Table 6

Comparison of flood inundation areas in the statistical periods for floods with different return periods

\begin{tabular}{|llll|}
\hline \multirow{2}{*}{ Return period (year) } & \multicolumn{2}{l}{ Flood Zoning Area (ha) } & Percentage of change (\%) \\
\cline { 2 - 3 } & Period 1979-2009 & Period 1979-2019 & \\
\hline 2 & 16.79 & 16.8 & +0.1 \\
\hline 5 & 33 & 38 & +15 \\
\hline 10 & 47 & 84 & +79 \\
\hline 20 & 64 & 89 & +39 \\
\hline 25 & 71 & 98 & +38 \\
\hline 50 & 93 & 133 & +43 \\
\hline 100 & 113 & 173 & +53 \\
\hline
\end{tabular}

The evaluation of the results of two periods in Table 6, flood zones indicates that flood depth has been increased and the inundation area has become wider. According to Table 6, the difference between the area of inundation zones for the return periods of 2 and 5 years in two statistical periods is small, which is attributed to the small difference between the maximum discharges in the mentioned periods. 
For flood with a 10-year return period, a significant difference was observed between the inundation zones of two periods because of the change in land uses and their maximum discharge; as the result of the extension in the impervious surfaces in the second period, more runoff was generated. A similar trend was observed for the floods with return periods of 20 and 25 years, and a significant increase in the inundation zones was observed. For the floods of 50 and 100-year, in addition to the end of the channel, there was also a significant difference in the flood inundation area at the beginning of the channel between the second and first periods. Moreover, the results show the certain change in rainfall and impervious surface leads to the higher order of change in flood inundation areas. For example, in the case of a 100-year scenario, around a 15\% increase in rainfall depth accompanied with the increase of impervious surface in the catchment lead to a $35 \%$ increase in a peak discharge of surface runoff which ultimately extends the flood inundation zone more than $50 \%$. The flood inundation zone of the 100 -year flood for the first and second periods is shown in Figure 10.

\subsection{The evaluation of economic impacts}

For the evaluation of economic impacts, damage to different properties and their contents were considered. Damages of floods with different return periods for two considered periods are separately analyzed and compared (see Table 7). 
Table 7

The economic damage of the two study periods for floods with different return periods

\begin{tabular}{|c|c|c|c|c|c|}
\hline $\begin{array}{l}\text { Return } \\
\text { period } \\
\text { (year) }\end{array}$ & Period & $\begin{array}{l}\text { Damage to building } \\
\text { structures (\$US) }\end{array}$ & $\begin{array}{l}\text { Damage to } \\
\text { building content } \\
\text { (SUS) }\end{array}$ & $\begin{array}{l}\text { Total } \\
\text { damage } \\
\text { (\$US) }\end{array}$ & $\begin{array}{l}\text { Percentage of changes in } \\
\text { damage for two period }\end{array}$ \\
\hline \multirow[t]{2}{*}{2} & $\begin{array}{l}1979- \\
2009\end{array}$ & 665,240 & 37,281 & 702,521 & \multirow[t]{2}{*}{-0.1} \\
\hline & $\begin{array}{l}1979- \\
2019\end{array}$ & 664,800 & 37,261 & 702,061 & \\
\hline \multirow[t]{2}{*}{5} & $\begin{array}{l}1979- \\
2009\end{array}$ & 777,258 & 49,851 & 827,109 & \multirow[t]{2}{*}{+9} \\
\hline & $\begin{array}{l}1979- \\
2019\end{array}$ & 842,012 & 60,791 & 902,803 & \\
\hline \multirow[t]{2}{*}{10} & $\begin{array}{l}1979- \\
2009\end{array}$ & 906,745 & 66,591 & 973,336 & \multirow[t]{2}{*}{+832} \\
\hline & $\begin{array}{l}1979- \\
2019\end{array}$ & $8,963,478$ & 107,015 & $9,070,493$ & \\
\hline \multirow[t]{2}{*}{20} & $\begin{array}{l}1979- \\
2009\end{array}$ & $6,495,653$ & 80,076 & $6,575,729$ & \multirow[t]{2}{*}{+41} \\
\hline & $\begin{array}{l}1979- \\
2019\end{array}$ & $9,157,148$ & 112,529 & $9,269,677$ & \\
\hline \multirow[t]{2}{*}{25} & $\begin{array}{l}1979- \\
2009\end{array}$ & $7,521,385$ & 85,964 & $7,607,349$ & \multirow[t]{2}{*}{+48} \\
\hline & $\begin{array}{l}1979- \\
2019\end{array}$ & $11,169,177$ & 127,477 & $11,296,654$ & \\
\hline \multirow[t]{2}{*}{50} & $\begin{array}{l}1979- \\
2009\end{array}$ & $9,292,187$ & 118,686 & $9,410,873$ & \multirow[t]{2}{*}{+61} \\
\hline & $\begin{array}{l}1979- \\
2019\end{array}$ & $15,004,854$ & 193,289 & $15,198,143$ & \\
\hline \multirow[t]{2}{*}{100} & $\begin{array}{l}1979- \\
2009\end{array}$ & $13,296,059$ & 152,092 & $13,448,151$ & \multirow[t]{2}{*}{+110} \\
\hline & $\begin{array}{l}1979- \\
2019\end{array}$ & $27,893,622$ & 350,386 & $28,244,008$ & \\
\hline
\end{tabular}

As it can be seen in Table7, since the flood inundation area was decreased for the 2-year flood in the second period, despite the same land use conditions, the flood damage was decreased by $0.1 \%$. For the 5 -year flood, damage of the second period was increased by $9 \%$ compared to the first one due to the extension in residential areas located in the flood zone. For the 10-year flood, the damage was increased by eight times due to the significant difference between the flood inundation zones of two study periods and land uses in the area.

Furthermore, the results in Table 7 provide an insight to the authorities in Tehran city about the potential damages of floods threating the area and a basis for the assessment of various flood mitigation measures and their priorities. Tehran municipality has studied various flood mitigation measures, including enlargement of channels, bottleneck modifications, construction of additional channels, and detention ponds in various parts of the city 
which the study area here was also included (Tehran Municipality, 2011). The analyses in this research can help to prioritize the measures from the economical aspect and determine the cost-effective measures by the same modeling approach developed here. From the academic point of view, the results of this paper demonstrate how much the non-stationarity of rainfall and urbanization could influence on the flood regime and its consequences in a dense semi-urban area. The result indicates that the socio-hydrological system in the catchment is completely chaotic, where a $15 \%$ change in rainfall depth and less than $2 \%$ in surface land cover (in terms of CN numbers) could result in more than $50 \%$ change in flood zones and more than $100 \%$ change in flood damages.

\section{Conclusions}

This part presents the conclusions from this study. In this research, results showed that the non-stationarity of rainfalls led to the decrease of extreme rainfalls with low return periods and the increase of medium and high return periods. By increasing the return period of floods, the two factors of non-stationary rainfall and urban development become more important. Nevertheless, the effect of the non-stationarity of rainfalls on increasing the surface runoff was nearly three times more significant than the urban development for a mountainous-urbanized catchment. It is also worth mentioning that the studied socio-hydrological system is completely dynamic. When non-stationary rainfall and urbanization are considered separately, they resulted in nearly $12 \%$ and $5 \%$ increase of surface runoff, respectively, but together they led to $18 \%$ increase in surface runoff, $38 \%$ increase of inundation areas, and $136 \%$ increase in flood damages, in average. Related to the estimated damages, in addition to inundation area, the type of land uses extended during the urban development process also affected the amount of damage such that in the case of a 10-year flood, the effect of the land use type on damage was more than the extent of the flood inundation area. Furthermore, the flooding area was more important than the flooding depth on damage values.

\section{Declarations}

\section{Funding}

None

\section{Conflicts of interest/Competing interests}

None

\section{Ethics approval}

Not applicable

\section{Consent to participate}

Not applicable

\section{Consent for publication}

The authors give their full consentfor the publication of this manuscript.

\section{Availability of data and material}


Not applicable

Code availability

Not applicable

Authors' contributions

Fatemeh Yavari:Conceptualization,Methodology, Modeling, Writing-original draft, Visualization

Seyyed Ali Akbar Salehi Neyshabouri: Supervision, Methodology, Review \& Editing

Jafar Yazdi: Supervision, Methodology, Review \& Editing

Amir Molajou: Conceptualization, Formal analysis, Review \& Editing

Acknowledgment

None

\section{References}

1. Arrighi, C., \& Campo, L. (2019). Effects of digital terrain model uncertainties on high-resolution urban flood damage assessment. Journal of Flood Risk Management, 12(S2), e12530.

2. Campana, N. A., \& Tucci, C. E. (2001). Predicting floods from urban development scenarios: case study of the Dilúvio Basin, Porto Alegre, Brazil. Urban water, 3(1-2), 113-124.

3. Chen, A. S., Hammond, M. J., Djordjević, S., Butler, D., Khan, D. M., \& Veerbeek, W. (2016). From hazard to impact: Flood damage assessment tools for mega cities. Natural Hazards, 82(2), 857-890.

4. Chow, V. T., Maidment, D. R., \& Mays, L. W. (1962). Applied hydrology. Journal of Engineering Education, 308, 1959.

5. Cutter, S. L., Emrich, C. T., Gall, M., \& Reeves, R. (2018). Flash flood risk and the paradox of urban development. Natural Hazards Review, 19(1), 05017005.

6. Dutta, D., Herath, S., \& Musiake, K. (2003). A mathematical model for flood loss estimation. Journal of hydrology, 277(1-2), 24-49.

7. Freni, G., La Loggia, G., \& Notaro, V. (2010). Uncertainty in urban flood damage assessment due to urban drainage modelling and depth-damage curve estimation. Water Science and Technology, 61(12), 2979-2993.

8. Hallegatte, S., Green, C., Nicholls, R. J., \& Corfee-Morlot, J. (2013). Future flood losses in major coastal cities. Nature climate change, 3(9), 802-806.

9. Hammond, M. J., Chen, A. S., Djordjević, S., Butler, D., \& Mark, O. (2015). Urban flood impact assessment: A state-of-the-art review. Urban Water Journal, 12(1), 14-29.

10. Hammond, M., Chen, A. S., Batica, J., Butler, D., Djordjević, S., Gourbesville, P., \& Veerbeek, W. (2018). A new flood risk assessment framework for evaluating the effectiveness of policies to improve urban flood resilience. Urban Water Journal, 15(5), 427-436.

11. Henonin, J., Russo, B., Mark, O., \& Gourbesville, P. (2013). Real-time urban flood forecasting and modelling-a state of the art. Journal of Hydroinformatics, 15(3), 717-736. 
12. Hodgkins, G. A., Dudley, R. W., Archfield, S. A., \& Renard, B. (2019). Effects of climate, regulation, and urbanization on historical flood trends in the United States. Journal of Hydrology, 573, 697-709.

13. Jamali, B., Löwe, R., Bach, P. M., Urich, C., Arnbjerg-Nielsen, K., \& Deletic, A. (2018). A rapid urban flood inundation and damage assessment model. Journal of Hydrology, 564, 1085-1098.

14. James, L. D. (1965). Using a digital computer to estimate the effects of urban development on flood peaks. Water Resources Research, 1(2), 223-234.

15. Jiang, Y., Zevenbergen, C., \& Ma, Y. (2018). Urban pluvial flooding and stormwater management: A contemporary review of China's challenges and "sponge cities" strategy. Environmental science \& policy, 80, 132-143.

16. Jiménez-Jiménez, S. I., Ojeda-Bustamante, W., Ontiveros-Capurata, R. E., \& Marcial-Pablo, M. D. J. (2020). Rapid urban flood damage assessment using high resolution remote sensing data and an object-based approach. Geomatics, Natural Hazards and Risk, 11(1), 906-927.

17. Liu, Y. B., De Smedt, F., Hoffmann, L., \& Pfister, L. (2005). Assessing land use impacts on flood processes in complex terrain by using GIS and modeling approach. Environmental modeling \& assessment, 9(4), $227-235$.

18. Lørup, J. K., Refsgaard, J. C., \& Mazvimavi, D. (1998). Assessing the effect of land use change on catchment runoff by combined use of statistical tests and hydrological modelling: case studies from Zimbabwe. Journal of hydrology, 205(3-4), 147-163.

19. Maksimović, Č., Prodanović, D., Boonya-Aroonnet, S., Leitao, J. P., Djordjević, S., \& Allitt, R. (2009). Overland flow and pathway analysis for modelling of urban pluvial flooding. Journal of Hydraulic Research, 47(4), 512523.

20. Mark, O., Weesakul, S., Apirumanekul, C., Aroonnet, S. B., \& Djordjević, S. (2004). Potential and limitations of 1D modelling of urban flooding. Journal of Hydrology, 299(3-4), 284-299.

21. Martins, R., Leandro, J., \& Djordjević, S. (2018). Influence of sewer network models on urban flood damage assessment based on coupled 1D/2D models. Journal of Flood Risk Management, 11, S717-S728.

22. Merz, B., Kreibich, H., Schwarze, R., \& Thieken, A. (2010). Review article" Assessment of economic flood damage". Natural Hazards and Earth System Sciences, 10(8), 1697-1724.

23. Miller, J. D., Kim, H., Kjeldsen, T. R., Packman, J., Grebby, S., \& Dearden, R. (2014). Assessing the impact of urbanization on storm runoff in a peri-urban catchment using historical change in impervious cover. Journal of Hydrology, 515, 59-70.

24. Moftakhari, H. R., AghaKouchak, A., Sanders, B. F., \& Matthew, R. A. (2017). Cumulative hazard: The case of nuisance flooding. Earth's Future, 5(2), 214-223.

25. Ministry of Energy (2016). The report of "Flood Damage Consideration", The Office of Water and Wastewater Designs and Standards, Report No. 164, (in Farsi).

26. Mubeen, A., Ruangpan, L., Vojinovic, Z., Sanchez Torrez, A., \& Plavšić, J. (2021). Planning and suitability assessment of large-scale nature-based solutions for flood-risk reduction. Water Resources Management, 35(10), 3063-3081.

27. Nirupama, N., \& Simonovic, S. P. (2007). Increase of flood risk due to urbanisation: A Canadian example. Natural Hazards, 40(1), 25-41.

28. Nofal, O. M., \& Van De Lindt, J. W. (2020). Understanding flood risk in the context of community resilience modeling for the built environment: Research needs and trends. Sustainable and Resilient Infrastructure, 1-17. 
29. Notaro, V., De Marchis, M., Fontanazza, C. M., La Loggia, G., Puleo, V., \& Freni, G. (2014). The effect of damage functions on urban flood damage appraisal. Procedia Engineering, 70, 1251-1260.

30. Park, K., \& Lee, M. H. (2019). The development and application of the urban flood risk assessment model for reflecting upon urban planning elements. Water, 11(5), 920.

31. Pingel, N., \& Ford, D. (2004). Interior floodplain flood-damage reduction study. Journal of water resources planning and management, 130(2), 123-130.

32. Ranzi, R., Bochicchio, M., \& Bacchi, B. (2002). Effects on floods of recent afforestation and urbanisation in the Mella River (Italian Alps). Hydrology and Earth System Sciences, 6(2), 239-254.

33. Saghafian, B., Farazjoo, H., Bozorgy, B., \& Yazdandoost, F. (2008). Flood intensification due to changes in land use. Water resources management, 22(8), 1051-1067.

34. Salas, J. D., \& Obeysekera, J. (2014). Revisiting the concepts of return period and risk for nonstationary hydrologic extreme events. Journal of Hydrologic Engineering, 19(3), 554-568.

35. Seyoum, S. D., Vojinovic, Z., Price, R. K., \& Weesakul, S. (2012). Coupled 1D and noninertia 2D flood inundation model for simulation of urban flooding. Journal of hydraulic engineering, 138(1), 23-34.

36. Skougaard Kaspersen, P., Høegh Ravn, N., Arnbjerg-Nielsen, K., Madsen, H., \& Drews, M. (2017). Comparison of the impacts of urban development and climate change on exposing European cities to pluvial flooding. Hydrology and Earth System Sciences, 21(8), 4131-4147.

37. Söderholm, K., Pihlajamäki, M., Dubrovin, T., Veijalainen, N., Vehviläinen, B., \& Marttunen, M. (2018). Collaborative planning in adaptive flood risk management under climate change. Water Resources Management, 32(4), 1383-1397.

38. Song, J. Y., \& Chung, E. S. (2016). Robustness, uncertainty and sensitivity analyses of the TOPSIS method for quantitative climate change vulnerability: a case study of flood damage. Water Resources Management, $30(13), 4751-4771$.

39. Suriya, S., \& Mudgal, B. V. (2012). Impact of urbanization on flooding: The Thirusoolam sub watershed-A case study. Journal of hydrology, 412, 210-219.

40. Tate, E., Muñoz, C., \& Suchan, J. (2015). Uncertainty and sensitivity analysis of the HAZUS-MH flood model. Natural Hazards Review, 16(3), 04014030.

41. Ten Veldhuis, J. A. E. (2011). How the choice of flood damage metrics influences urban flood risk assessment. Journal of Flood Risk Management, 4(4), 281-287.

42. Tsakiris, G. (2014). Flood risk assessment: concepts, modelling, applications. Natural Hazards and Earth System Sciences, 14(5), 1361-1369.

43. USACE HEC-RAS 5.0 User's Manual, 2016.

44. US Army Corps of Engineers (USACE) HEC-FIA. flood impact analysis: User's manual, 2012.

45. U.S. Army Corps of Engineers (USACE). Economic Guidance Memorandum (EGM) 04-01, Generic DepthDamage Relationships for Residential Structures with Basements; U.S. Army Corps of Engineers (USACE): Washington, DC, USA, 2003.

46. Vasiliades, L., Galiatsatou, P., \& Loukas, A. J. W. R. M. (2015). Nonstationary frequency analysis of annual maximum rainfall using climate covariates. Water Resources Management, 29(2), 339-358.

47. Vogel, R. M., Yaindl, C., \& Walter, M. (2011). Nonstationarity: flood magnification and recurrence reduction factors in the United States 1. JAWRA Journal of the American Water Resources Association, 47(3), 464-474. 
48. Wang, W. C., Chau, K. W., Cheng, C. T., \& Qiu, L. (2009). A comparison of performance of several artificial intelligence methods for forecasting monthly discharge time series. Journal of hydrology, 374(3-4), 294-306.

49. Wedawatta, G., Ingirige, B., \& Proverbs, D. (2014). Small businesses and flood impacts: the case of the 2009 flood event in C ockermouth. Journal of Flood Risk Management, 7(1), 42-53.

50. World Meteorological Organization (1969). Manual for Depth-Area-Duration Analysis of Storm Precipitation, No. 237, Geneva

51. Wobus, C., Lawson, M., Jones, R., Smith, J., \& Martinich, J. (2014). Estimating monetary damages from flooding in the U nited S tates under a changing climate. Journal of Flood Risk Management, 7(3), $217-229$.

52. Yang, L., Li, J., Kang, A., Li, S., \& Feng, P. (2020). The Effect of Nonstationarity in Rainfall on Urban Flooding Based on Coupling SWMM and MIKE21. Water Resources Management, 34(4).

53. Zhou, Q., Leng, G., Su, J., \& Ren, Y. (2019). Comparison of urbanization and climate change impacts on urban flood volumes: Importance of urban planning and drainage adaptation. Science of the Total Environment, 658, 24-33.

\section{Figures}




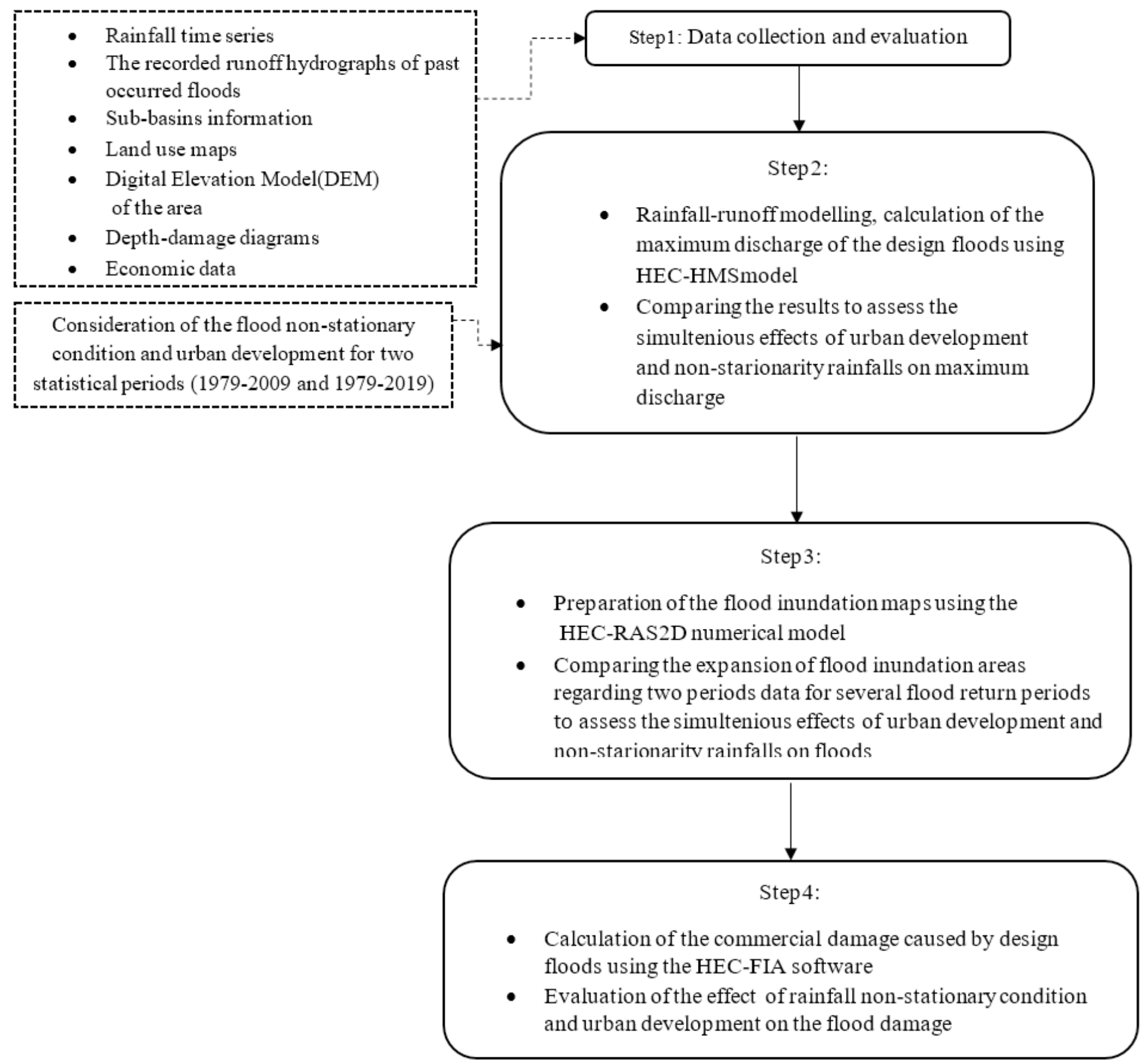

Figure 1

The thematic of the study process 


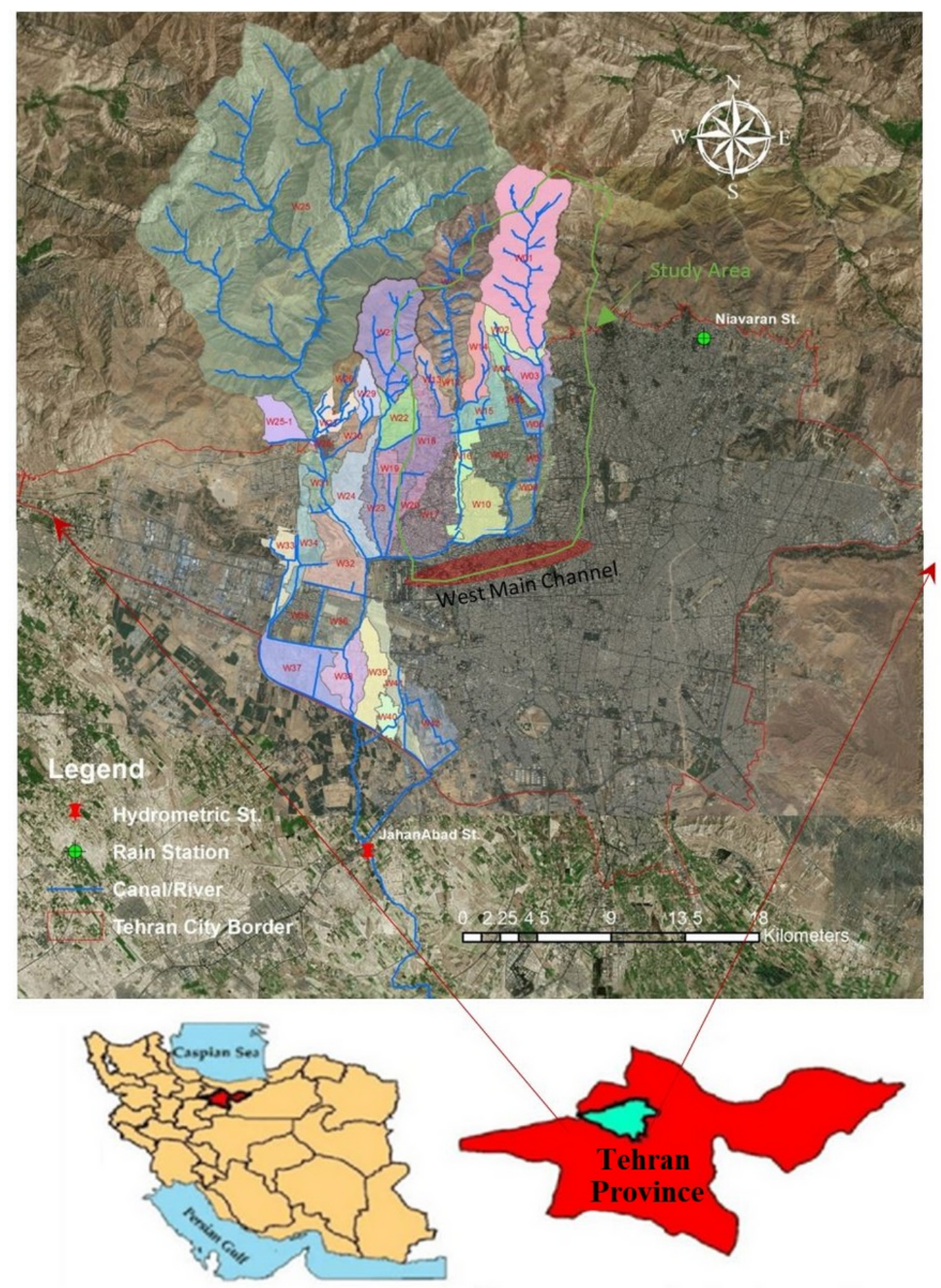

Figure 2

The location of West Main Channel Catchment in Iran 
a)

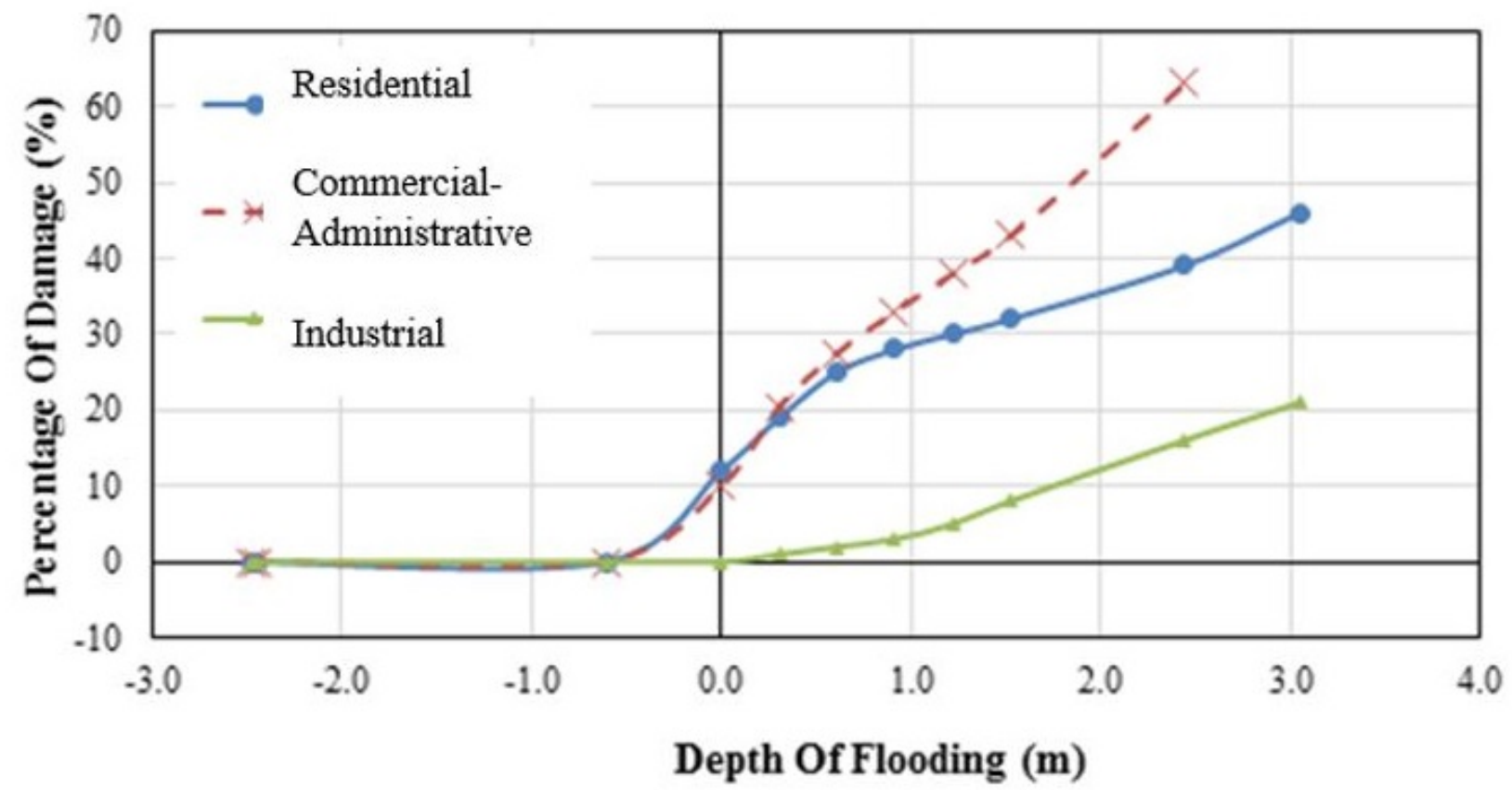

b)

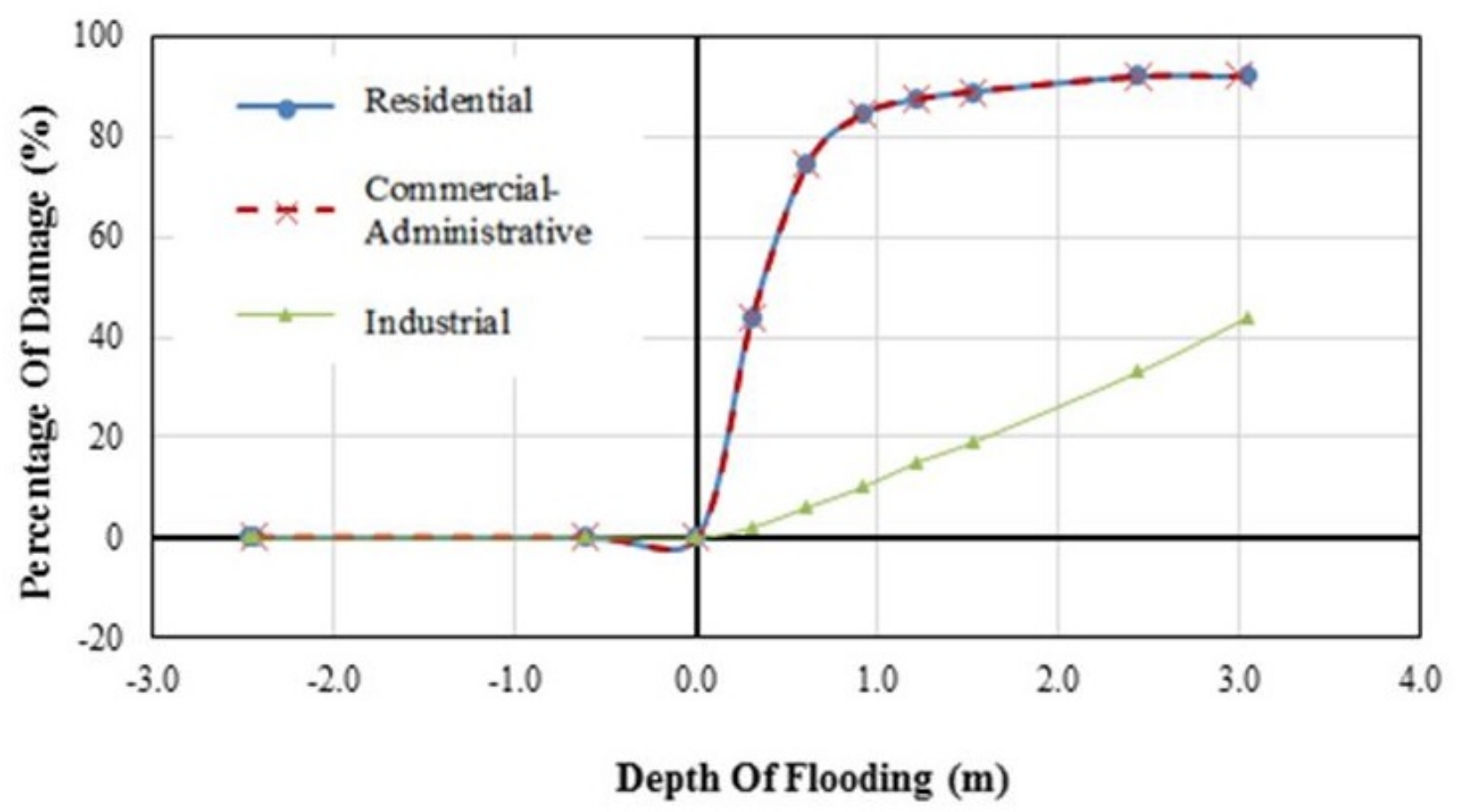

Figure 3

The depth-damage curve of the a) structure b) building contents (USACE, 2003) 


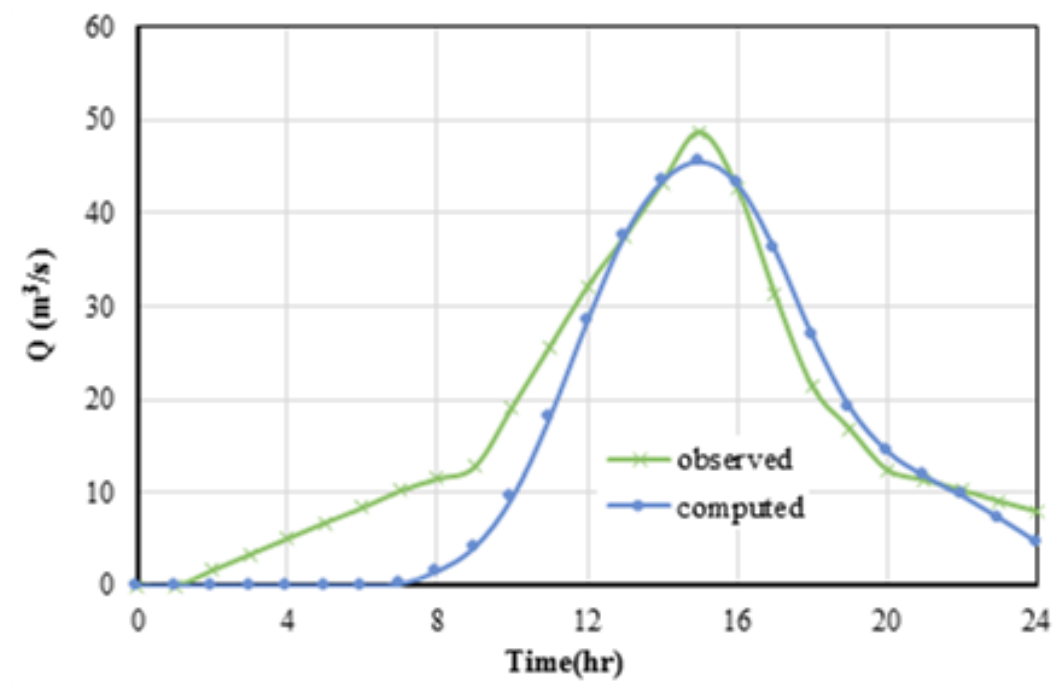

Figure 4

Calibration of the HEC-HMS model in the flood event occurred on 08/29/2011

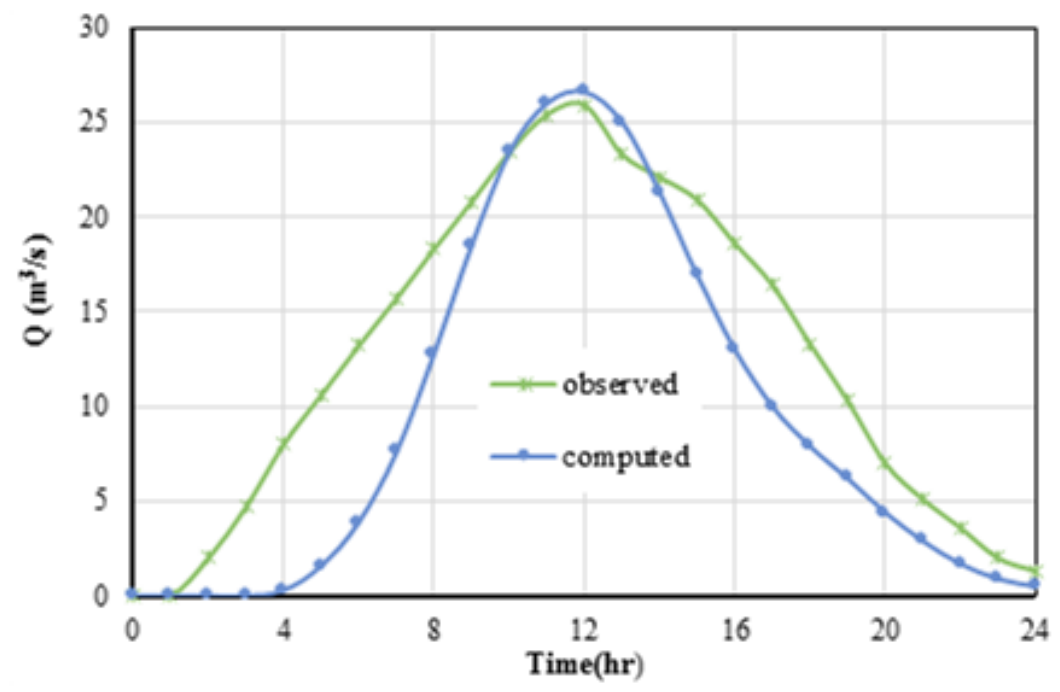

Figure 5

Verification of the HEC-HMS model using the flood event on 03/31/2009

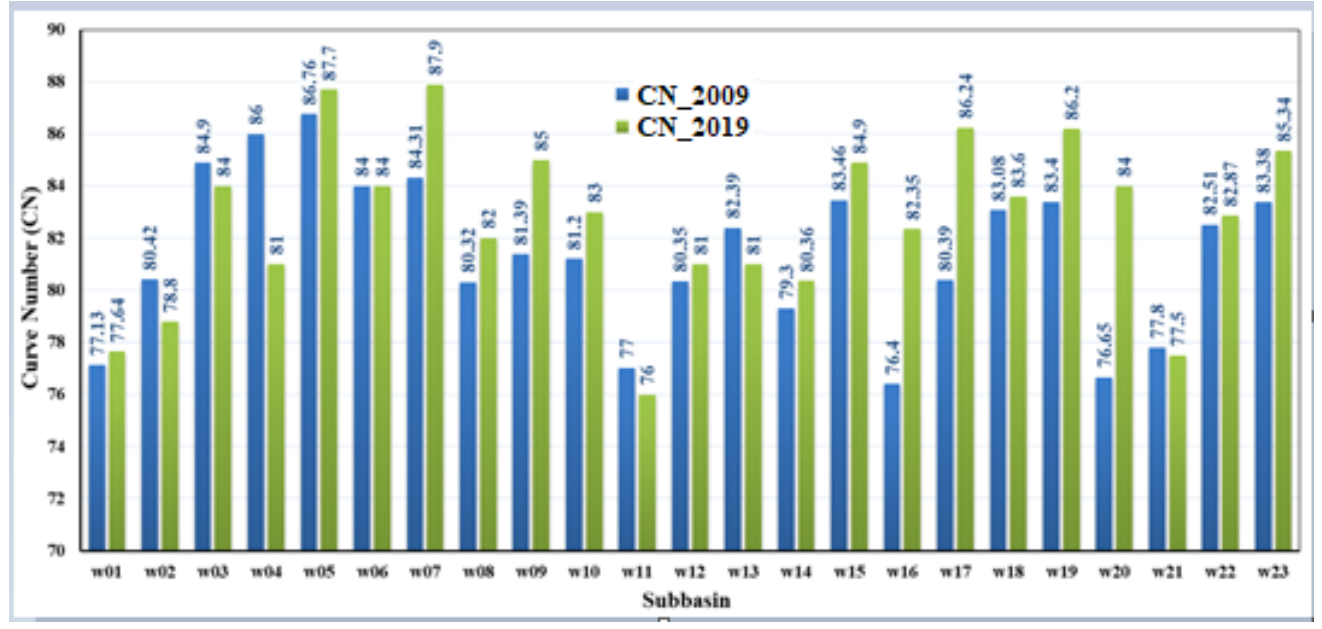

Figure 6 
Calculated $\mathrm{CN}$ values and their changes for two different time periods

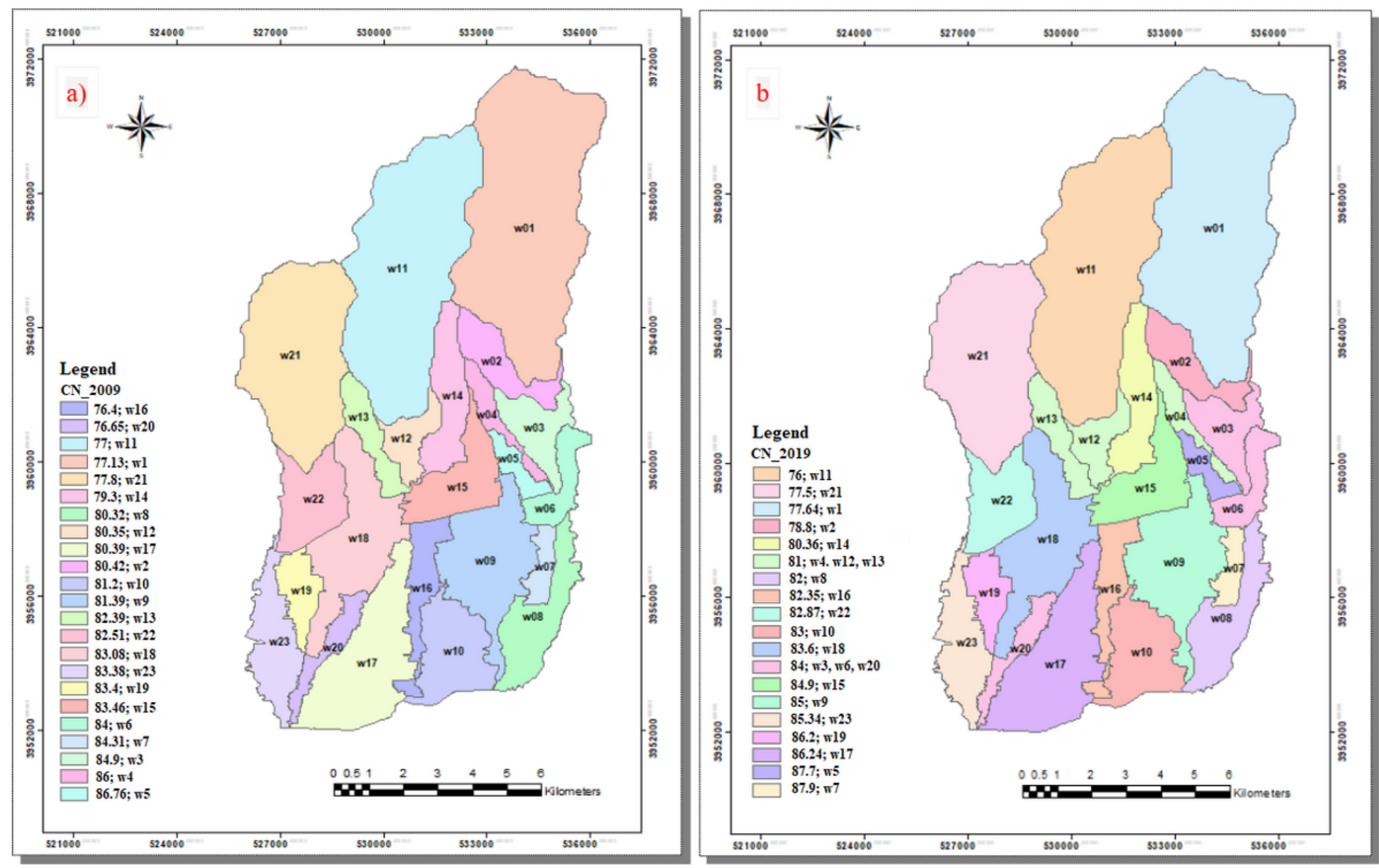

Figure 7

CN map for two periods of analysis in the study area, a) 2009, b) 2019 


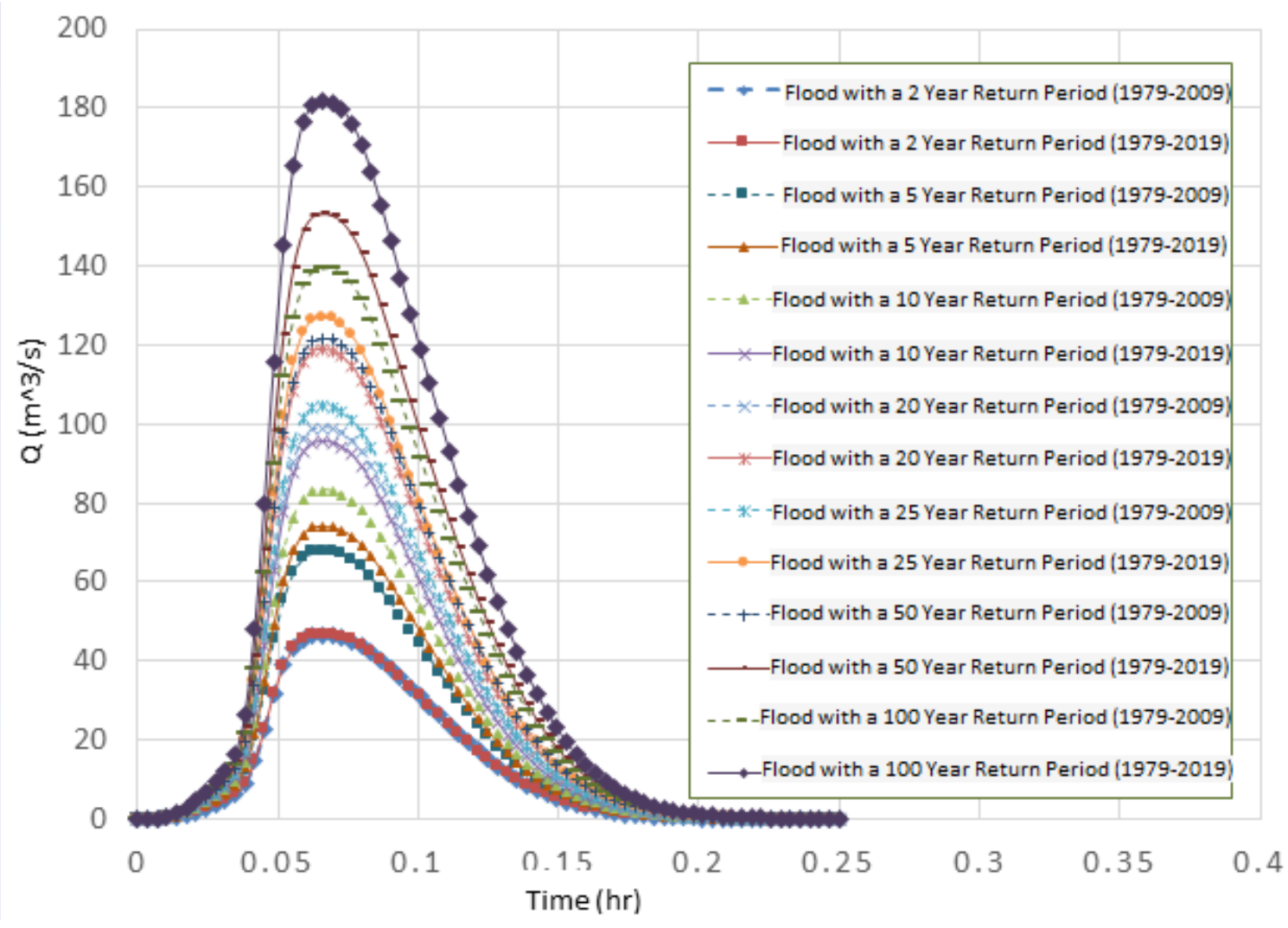

Figure 8

Comparison of the outflow hydrographs of the catchment in two statistical periods for different return periods 

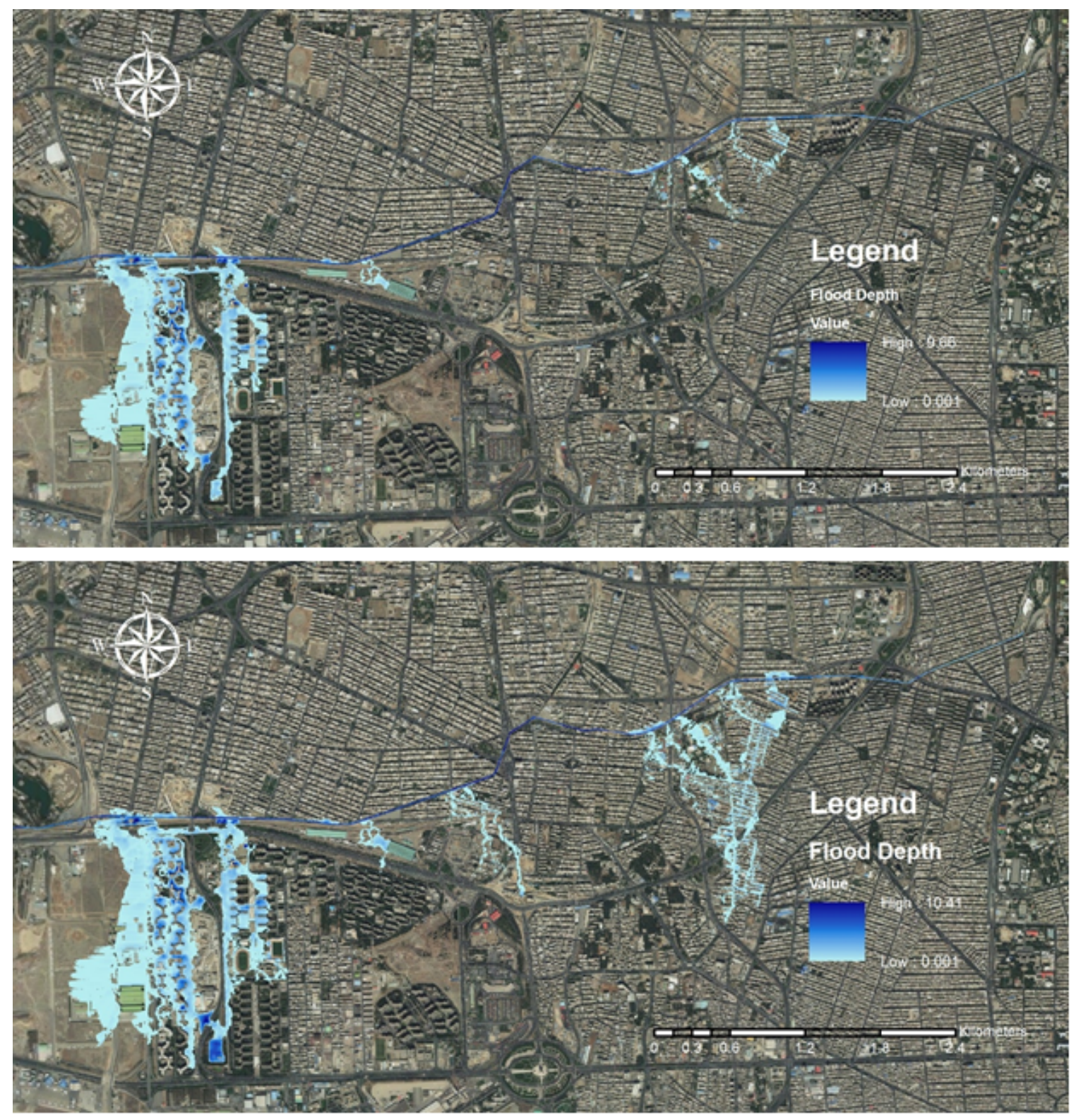

\section{Figure 9}

Comparison of the flood inundation areas considering a return period of 100 years, (a) 1979-2009 period, and (b) 1979-2019 period 